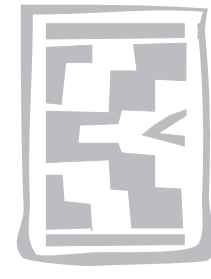

\title{
Parasites of domestic and wild animals in South Africa. XLVI. Oestrid fly larvae of sheep, goats, springbok and black wildebeest in the Eastern Cape Province
}

\section{I.G. HORAK}

Department of Veterinary Tropical Diseases, Faculty of Veterinary Science, University of Pretoria, Onderstepoort, 0110, South Africa.E-mail: ivan.horak@up.ac.za

\begin{abstract}
HORAK, I.G. 2005. Parasites of domestic and wild animals in South Africa. XLVI. Oestrid fly larvae of sheep, goats, springbok and black wildebeest in the Eastern Cape Province. Onderstepoort Journal of Veterinary Research, 72:315-320

Merino sheep in Thornveld, Dorper sheep and Angora goats in inland Valley Bushveld, Angora goats and Boer goats in Valley Bushveld on the coastal plateau, and springbok, Antidorcas marsupialis, and black wildebeest, Connochaetes gnou, in Karroid Mountainveld, all in the Eastern Cape Province, were examined for the larvae of nasal bot flies. The sheep and goats were infested with the larvae of Oestrus ovis, and Dorper sheep and Boer goats harboured more larvae than Angora goats on the same farms. Most infestation was present from November to May in Merino sheep in Thornveld, from February to June in Dorper sheep in inland Valley Bushveld, and from May to September in Angora and Boer goats in Valley Bushveld on the coastal plateau. These patterns of seasonality appeared to be regulated by the severity of the summer temperatures at the various localities. The springbok were infested with the larvae of Rhinoestrus antidorcitis, most of which seemed to mature from June to August. All larval sages of Oestrus variolosus and Gedoelstia hässleri were present in the black wildebeest, and large numbers of $1^{\text {st }}$ instar larvae of $G$. hässleri appeared to accumulate on the dura of the wildebeest from June to August.
\end{abstract}

Keywords: Black wildebeest, Gedoelstia hässleri, goats, Oestrus ovis, Oestrus variolosus, Rhinoestrus antidorcitis, sheep, springbok

\section{INTRODUCTION}

The larvae of a large variety of fairly host-specific oestrid or nasal bot flies parasitize the nasal passages and paranasal sinuses of various host species in South Africa (Zumpt 1965). These flies belong to the genera Oestrus, with four species occurring in southern Africa, Rhinoestrus, with four species present here, Kirkioestrus, with a single species, and Gedoelstia, with at least two species. The best known of these flies is Oestrus ovis, the only nasal bot fly that is capable of completing its

Accepted for publication 20 June 2005-Editor larval development in sheep and goats. On the other hand blue wildebeest, Connochaetes taurinus, are hosts of the larvae of at least five of these flies in South Africa (Zumpt 1965; Horak, De Vos \& Brown 1983). However, despite the fact that approximately $70 \%$ of sheep and goats and virtually all blue and black wildebeest, Connochaetes gnou, bontebok, Damaliscus pygargus dorcas, and blesbuck, Damaliscus pygargus phillipsi, are infested with the larvae of nasal bot flies in this country (Horak 1977; Horak \& Butt 1977a, b; Horak et al. 1983; Louw 1989; Horak \& Boomker 1998), unless a determined effort is made to collect them their presence is often overlooked. The larvae that are probably most neglected are those of the genus Rhinoestrus, which 
are host-specific with individual species infesting unlikely hosts such as hippopotami, equids, suids, giraffes and antelopes in Africa (Zumpt 1965).

This paper records the species and numbers of oestrid larvae coincidentally collected from sheep, goats, springbok, Antidorcas marsupialis, and black wildebeest during surveys of helminths and/or ixodid ticks infesting these animals in the Eastern Cape Province.

\section{MATERIALS AND METHODS}

The localities at which the animals were examined, the number sampled on each occasion and the intervals between sampling have been described in the primary surveys on helminths and/or ticks (Boomker, Horak \& Maclvor 1989; Horak, Fourie, Novellie \& Williams 1991a; Horak, Knight \& Williams 1991b; Horak 2003), and will not be repeated here. The larvae of the various species of oestrid flies were recovered from the nasal passages and paranasal sinuses, and from the lungs and the dura mater of the survey animals as described by Malan, Reinecke \& Scialdo (1981) and Horak et al. (1983). The larval burdens of the sheep examined on the farms "Grasmere", "Reed Valley" and "Sidbury" have been combined, as have those of the Dorper sheep on the farm "Bucklands", and of the Angora and Boer goats on the farm "Brakhill" and expressed as monthly averages, irrespective of the year or years during which the surveys were conducted, in order to illustrate the seasonality of $O$. ovis larvae in sheep in veld types classified by Acocks (1988) as Eastern Province Thornveld or inland Valley Bushveld, and goats in Valley Bushveld on the coastal plateau, respectively.

\section{RESULTS AND DISCUSSION}

The sheep and goats were infested with the larvae of $O$. ovis, the springbok with those of Rhinoestrus antidorcitis and the black wildebeest with larvae of Oestrus variolosus and Gedoelstia hässleri (Table 1).

TABLE 1 Oestrid fly larvae from sheep, goats, springbok and black wildebeest in the Eastern Cape Province

\begin{tabular}{|c|c|c|c|c|c|c|c|}
\hline \multirow{2}{*}{ Host } & \multirow{2}{*}{ Veld type } & \multirow{2}{*}{$\begin{array}{l}\text { Number } \\
\text { examined }\end{array}$} & \multirow{2}{*}{$\begin{array}{l}\text { Number } \\
\text { infested }\end{array}$} & \multicolumn{4}{|c|}{ Number and instar of larvae collected } \\
\hline & & & & $1^{\text {st }}$ instar & $2^{\text {nd }}$ instar & $3^{\text {rd }}$ instar & Total \\
\hline \multirow[b]{2}{*}{ Merino sheep } & \multirow[b]{2}{*}{$\begin{array}{l}\text { Eastern Province } \\
\text { Thornveld }\end{array}$} & \multirow[b]{2}{*}{145} & \multirow[b]{2}{*}{59} & \multicolumn{4}{|c|}{ Oestrus ovis } \\
\hline & & & & 346 & 115 & 69 & 530 \\
\hline Dorper sheep & $\begin{array}{l}\text { Inland Valley } \\
\text { Bushveld }\end{array}$ & 48 & 44 & 544 & 132 & 97 & 773 \\
\hline Angora goats & $\begin{array}{l}\text { Inland Valley } \\
\text { Bushveld }\end{array}$ & 48 & 23 & 87 & 26 & 33 & 146 \\
\hline Angora goats & $\begin{array}{l}\text { Coastal plateau } \\
\text { Valley Bushveld }\end{array}$ & 24 & 15 & 63 & 16 & 32 & 111 \\
\hline \multirow[t]{2}{*}{ Boer goats } & $\begin{array}{l}\text { Coastal plateau } \\
\text { Valley Bushveld }\end{array}$ & 24 & 20 & 136 & 45 & 64 & 245 \\
\hline & \multirow[b]{2}{*}{ Karroid Mountainveld } & \multirow[b]{2}{*}{18} & \multirow[b]{2}{*}{17} & \multicolumn{4}{|c|}{ Rhinoestrus antidorcitis } \\
\hline Springbok* & & & & 654 & 55 & 82 & 791 \\
\hline \multirow[b]{2}{*}{ Black wildebeest } & \multirow[b]{2}{*}{ Karroid Mountainveld } & \multirow[b]{2}{*}{10} & \multirow[b]{2}{*}{9} & \multicolumn{4}{|c|}{ Oestrus variolosus } \\
\hline & & & & 923 & 185 & 285 & 1393 \\
\hline \multirow[b]{2}{*}{ Black wildebeest } & \multirow[b]{2}{*}{ Karroid Mountainveld } & \multirow[b]{2}{*}{10} & \multirow[b]{2}{*}{10} & \multicolumn{4}{|c|}{ Gedoelstia hässleri } \\
\hline & & & & 2454 & 37 & 52 & 2543 \\
\hline
\end{tabular}

${ }^{*}+1$ O. variolosus $1^{\text {st }}$ instar larva 


\section{Oestrus ovis}

The sheep examined on the farms "Reed Valley" and "Sidbury" acted as "tracer" sheep in helminth surveys conducted on these farms (Horak 2003). Their burdens of $O$. ovis larvae could have been affected by the fact that they had been treated with anthelmintics (which may have had insecticide properties) and then put out to graze with other sheep for a month before slaughter. The sheep on "Grasmere" were, however, not treated and yet only four of the 18 sheep examined there were infested, indicating that the prevalence of infestation in the region was in any event low, even without possible insecticide intervention. If the Dorper sheep and Angora goats on the farm "Bucklands" and the Angora and Boer goats on the farm "Brakhill" were treated at all, such treatment was administered at least 3 or 4 months prior to slaughter.

The prevalence of infestation and the larval burdens of Dorper sheep on "Bucklands" were noticeably higher than those of Angora goats on the same farm, and those of Boer goats on "Brakhill" were greater than those of Angora goats on the same farm. Horak (1977) noted that the prevalence of infestation and the average larval burdens of 199 Dorper-type sheep he examined at the Pretoria Municipal Abattoir marginally exceeded those of the 338 Merino-type sheep he examined at the same facility, namely 75.9 and $71.6 \%$, and 16.5 and 14.2 larvae, respectively. No direct comparisons between Dorper and Merino sheep were possible in the present survey because of the very different vegetation regions in which the two sheep breeds grazed, as well as the fact that most of the Merino sheep were potentially only exposed to infestation for a month on the survey farms. Horak \& Butt (1977a) noted that the $73.8 \%$ prevalence of infestation in goats slaughtered at the Johannesburg Municipal Abattoir was virtually identical to the $73.4 \%$ prevalence in sheep recorded by Horak (1977) at the Pretoria Abattoir, but that the average burden of 4.4 larvae in goats was considerably lower than the 15.2 larvae collected from sheep. The overall prevalence of infestation in goats examined at the two localities in the present survey was $60.4 \%$ and the average burden consisted of 5.2 larvae.

Whether the apparent preferences of the flies for sheep as opposed to goats and for Dorper sheep and Boer goats as opposed to Merino sheep and Angora goats, respectively, are real, or are a result of other factors, such as human intervention, could not be determined in this survey. If real the differences in the larval burdens could be due to innate
Oestrus ovis-Sheep, Thornveld A

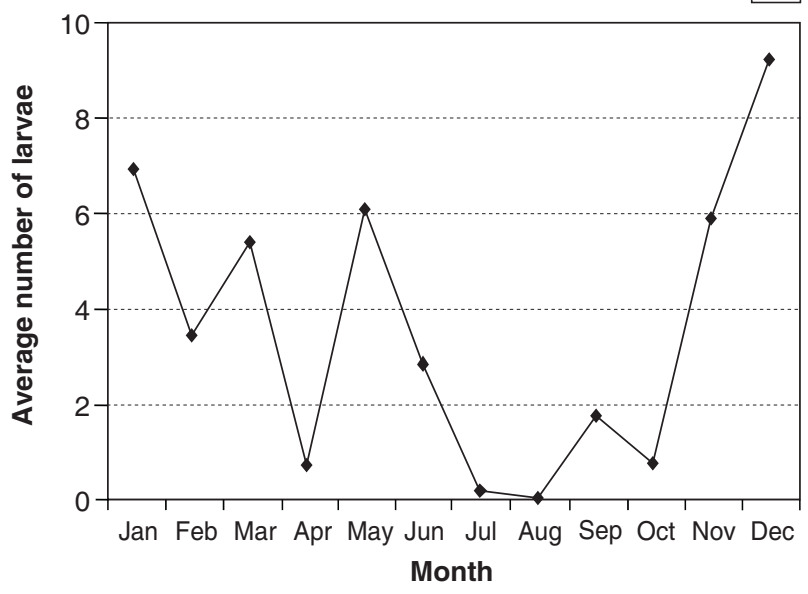

Oestrus ovis-Sheep, Valley Bushveld B

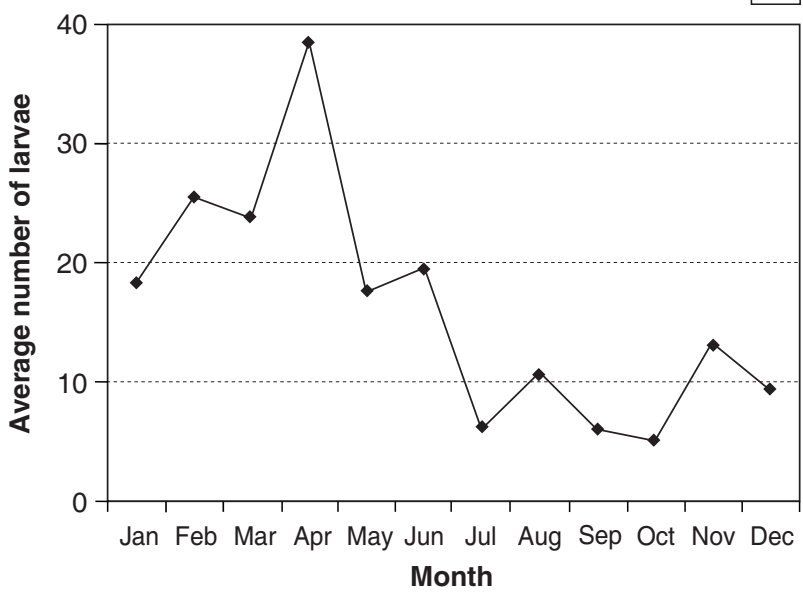

Oestrus ovis-Goats, Valley Bushveld

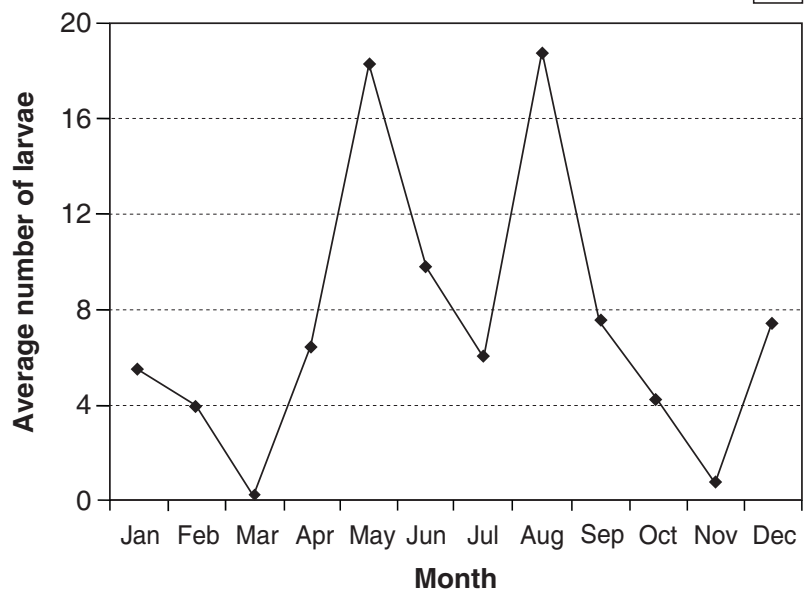

$\rightarrow-$ Larvae (all instars)

FIG. 1 The seasonal occurrence in the Eastern Cape Province of the larvae of Oestrus ovis in the nasal passages and paranasal sinuses of (A) Merino sheep in Thornveld, (B) Dorper sheep in inland Valley Bushveld, and (C) Angora and Boer goats in Valley Bushveld on the coastal plateau 
breed susceptibility, or more effective clearing of the nasal passages, or more efficient fly avoidance behaviour, or because Dorper sheep and Boer goats spend more time out in the open and less in the shade than Merino sheep and Angora goats, respectively, because of their shorter hair coats and greater heat tolerance.

In his study of the biology of $O$. ovis in sheep in winter rainfall areas of the Western Cape Province, Louw (1989) stated that the larvae of the fly had their own unique seasonal pattern of infestation in animals on each farm. A similar situation appears to pertain in the present study between animals on farms in Eastern Province Thornveld, in inland Valley Bushveld and in Valley Bushveld on the coastal plateau (Fig. 1).

Most Infestation appeared to take place from early summer to autumn in sheep on the farms in Thornveld (Fig. 1A). Mean maximum air temperature on these farms ranges between approximately $20^{\circ} \mathrm{C}$ in winter and $30^{\circ} \mathrm{C}$ in summer, and the mean annual rainfall of approximately $500 \mathrm{~mm}$ is non-seasonal, with most falling during spring and summer. In the inland Valley Bushveld most infestation occurred from late summer to autumn (Fig. 1B). Mean maximum air temperatures on this farm range between approximately $19^{\circ} \mathrm{C}$ in winter and $33^{\circ} \mathrm{C}$ in summer. Long-term annual rainfall is $484 \mathrm{~mm}$ and is nonseasonal with slightly more than $300 \mathrm{~mm}$ falling between October and March. Most infestation took place in the goats in Valley Bushveld on the coastal plateau during the cooler autumn to spring months. Annual rainfall on this farm is only $300 \mathrm{~mm}$, nonseasonal, and mean maximum temperatures vary between $23^{\circ} \mathrm{C}$ in winter and $32^{\circ} \mathrm{C}$ in summer.

Rogers \& Knapp (1973) demonstrated that relative humidity apparently does not influence the proportion of flies that emerge from pupae, but that temperature does. They found that a constant temperature either below $16^{\circ} \mathrm{C}$ or above $32^{\circ} \mathrm{C}$ was fatal to pupae. The results of the present survey appear to confirm their observations with the severity of the summer temperatures governing the seasons during which larvae are deposited in and around the nostrils of sheep and goats in the Eastern Cape Province.

\section{Rhinoestrus antidorcitis}

The larvae of this fly are host specific to springbok (Zumpt 1965), and with the exception of one animal all the springbok were infested. The average burden of infested animals comprised 46.5 larvae
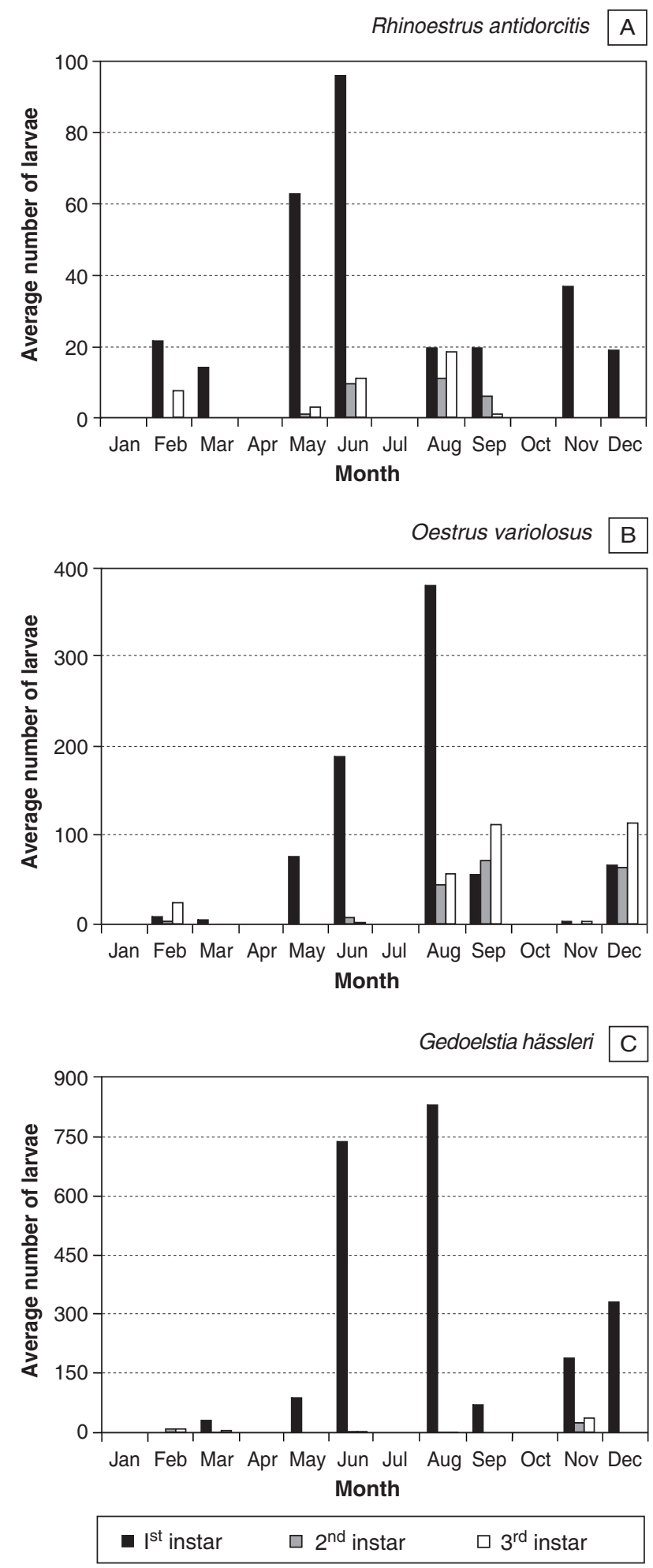

FIG. 2 The seasonal occurrence in the nasal passages and paranasal sinuses of larvae of (A) Rhinoestrus antidorcitis in springbok, (B) Oestrus variolosus in black wildebeest, and (C) Gedoelstia hässleri on the cranial dura and in the nasal passages and paranasal sinuses of black wildebeest in Karroid Mountainveld in the Eastern Cape Province. No springbok or black wildebeest were examined during January, April, July or October of any year 
(Table 1). De Villiers, Liversidge \& Reinecke (1985) recovered no $1^{\text {st }}$ instar larvae of $R$. antidorcitis from 48 springbok they examined in the Northern Cape Province, but 14 of the animals were infested with $2^{\text {nd }}$ and $3^{\text {rd }}$ stage larvae. They also recovered larvae of Rhinoestrus vanzyli from these antelopes, a fly not collected in the present survey.

The February and June to August peaks in seasonality currently observed for $3^{\text {rd }}$ stage larvae of $R$. antidorcitis (Fig. 2A), closely correspond to the January and June to September peaks in springbok in the Northern Cape Province (De Villiers et al. 1985). This pattern of seasonality implies that most cohorts of the fly complete a single life cycle annually. In this life cycle mature larvae would leave the nostrils in late winter and spring, flies would hatch from pupae and deposit $1^{\text {st }}$ instar larvae in and around the nostrils of the antelopes in spring and early summer, and the majority of these larvae would persist in the $1^{\text {st }}$ instar until autumn and early winter when development to the $2^{\text {nd }}$ and $3^{\text {rd }}$ instars takes place. This life cycle has the advantage that pupae are not exposed to the sub-zero temperatures experienced in the Mountain Zebra National Park during winter, or to the $34^{\circ} \mathrm{C}$ and higher summer temperatures. A similar life cycle has been proposed for Rhinoestrus usbekistanicus in Burchell's zebras, Equus burchelli, in north-eastern Mpumalanga Province (Horak, De Vos \& De Klerk 1984).

\section{Oestrus variolosus}

In South Africa the larvae of this fly infest the nasal passages of black and blue wildebeest, red hartebeest, Alcelaphus buselaphus caama, tsessebe, Damaliscus lunatus lunatus, and blesbuck (Zumpt 1965; Horak et al. 1983). Third stage larvae of this fly outnumbered those of Oestrus macdonaldi in 34 blesbuck examined in Limpopo Province (Horak \& Butt 1977b), whereas in black wildebeest in Gauteng Province the converse was true (Horak et al. 1983). On the other hand 55 blue wildebeest examined in Mpumalanga Province harboured no O. macdonaldi and only small numbers of $2^{\text {nd }}$ and $3^{\text {rd }}$ instar larvae of $O$. variolosus compared to large larval burdens of Oestrus aureoargentatus (Horak et al. 1983). The nine infested black wildebeest in the present study had average burdens of 154.8 larvae, and a single red hartebeest examined at the same time and in the same locality harboured eight $1^{\text {st }}$, three $2^{\text {nd }}$ and $243^{\text {rd }}$ instar larvae of this fly.

Most $3^{\text {rd }}$ instar larvae were present in the wildebeest from June to February (Fig. 2B), a time span almost identical to the July to February recorded in 34 bles- buck examined in Limpopo Province by Horak \& Butt (1977b).

\section{Gedoelstia hässleri}

Blue and black wildebeest are the preferred hosts of the larvae of this fly, which also infest red hartebeest, blesbuck and tsessebe in South Africa (Zumpt 1965; Horak \& Butt 1977b; Horak et al. 1983). All the black wildebeest examined in the present survey were infested and their average burden consisted of 254.3 larvae.

Flies belonging to this genus deposit $1^{\text {st }}$ instar larvae on the cornea or conjunctiva of the eyes of their hosts from where they migrate either via the optic nerve tract or artery to the subdural cavity and dura mater, and then via foramina in the cribriform plate and other foramina to the nasal passages, or they migrate via the ocular vascular system to the heart and thence to the lungs and trachea and via the soft palate to the nasal passages where they moult to the $2^{\text {nd }}$ instar (Basson 1966; Horak \& Butt 1977b). Horak et al. (1983) noted an erratic, but progressive increase in the numbers of $1^{\text {st }}$ stage Gedoelstia spp. larvae on the dura mater of blue wildebeest calves until they reach the age of approximately 13 months. Judging by the small numbers of $2^{\text {nd }}$ and $3^{\text {rd }}$ instar larvae that they recovered from the nasal passages and paranasal sinuses of the blue wildebeest they suggested that few of these larvae developed further, a phenomenon encountered also in the present survey. Particularly large burdens of $1^{\text {st }}$ instar larvae were present on the dura mater of those black wildebeest examined during June and August. This suggests that delay in larval development at this time of the year may be an overwintering strategy ensuring that pupae are not exposed to the harsh winter climate in the mountainous region of the Karoo in which the Mountain Zebra National Park is situated.

\section{General discussion}

The springbok and black wildebeest had considerably greater average larval burdens than the sheep or goats. This implies that the flies infesting the antelopes are more fecund than $\mathrm{O}$. ovis, or that there are greater numbers of the former flies present in the antelopes' habitat than $O$. ovis in the regions in which the sheep and goats were examined, or that large flocks of sheep and goats result in a dilution in the intensity of infestation, or that fly avoidance behaviour by the host species is less or more effective, or that immunity to infestation differs between hosts. A multitude of other possible reasons, however, exists. 


\section{ACKNOWLEDGEMENTS}

I am most grateful to Messrs John Weeks, Hylton Hart, James Turner and Tony Phillips for making their farms available to me for the conduct of these surveys, and to the members of the "Sidbury Study Group" for donating the Merino sheep slaughtered during the studies. I also greatly appreciate the contribution made by Mr F. Dorfling of the farm "Brakhill" who not only provided the study camp, but also the survey animals and labour to assist with the management of the goats. I am indebted to the South African National Parks for placing the animals as well as their staff and facilities in the Mountain Zebra National Park at my disposal. The assistance of Messrs M.M. Knight and E.J. Williams with processing the material for larval recovery and with the larval counts is greatly appreciated. This research was funded by grants from the Wool Board, the Mohair Board, the Meat Board and the Department of Agriculture.

\section{REFERENCES}

ACOCKS, J.P.H. 1988. Veld types of South Africa with accom panying veld type map, $3^{\text {rd }}$ ed. (Memoirs of the Botanical Survey of South Africa, no.57).

BASSON, P.A. 1966. Gedoelstial myiasis in antelopes of southern Africa. Onderstepoort Journal of Veterinary Research, 33: 77-92.

BOOMKER, J., HORAK, I.G. \& MACIVOR, K.M. DE F. 1989. Helminth parasites of grysbok, common duikers and Angora and Boer goats in the Valley Bushveld in the eastern Cape Province. Onderstepoort Journal of Veterinary Research, 56: 165-172.

DE VILLIERS, I.L., LIVERSIDGE, R. \& REINECKE, R.K. 1985 Arthropods and helminths in springbok (Antidorcas marsupialis) at Benfontein, Kimberley. Onderstepoort Journal of Veterinary Research, 52:1-11.

HORAK, I.G. 1977. Parasites of domestic and wild animals in South Africa. I. Oestrus ovis in sheep. Onderstepoort Journal of Veterinary Research, 44:55-63.
HORAK, I.G. \& BUTT, M.J. 1977a. Parasites of domestic and wild animals in South Africa. II. Oestris ovis in goats. Onderstepoort Journal of Veterinary Research, 44:65-67.

HORAK, I.G. \& BUTT, M.J. 1977b. Parasites of domestic and wild animals in South Africa. III. Oestrus spp. and Gedoelstia hässleri in the blesbok. Onderstepoort Journal of Veterinary Research, 44:113-118.

HORAK, I.G., DE VOS, V. \& BROWN, MOIRA R. 1983. Parasites of domestic and wild animals in South Africa. XVI. Helminth and arthropod parasites of blue and black wildebeest (Connochaetes taurinus and Connochaetes gnou). Onderstepoort Journal of Veterinary Research, 50:243-255.

HORAK, I.G., DE VOS, V. \& DE KLERK, B.D. 1984. Parasites of domestic and wild animals in South Africa. XVII. Arthropod parasites of Burchell's zebra, Equus burchelli, in the eastern Transvaal Lowveld. Onderstepoort Journal of Veterinary Research, 51:145-154.

HORAK, I.G., FOURIE, L.J., NOVELLIE, P.A. \& WILLIAMS, E.J. 1991a. Parasites of domestic and wild animals in South Africa. $X X V I$. The mosaic of ixodid tick infestations on birds and mammals in the Mountain Zebra National Park. Onderstepoort Journal of Veterinary Research, 58:125-136.

HORAK, I.G., KNIGHT, M.M. \& WILLIAMS, E.J. 1991b. Parasites of domestic and wild animals in South Africa. XXVIII. Helminth and arthropod parasites of Angora goats and kids in Valley Bushveld. Onderstepoort Journal of Veterinary Research, 58:253-260.

HORAK, I.G. \& BOOMKER, J. 1998. Parasites of domestic and wild animals in South Africa. XXXV. Ixodid ticks and bot fly larvae in the Bontebok National Park. Onderstepoort Journal of Veterinary Research, 65:205-211.

HORAK, I.G. 2003. Parasites of domestic and wild animals in South Africa. XLII. Helminths of sheep on four farms in the Eastern Cape Province. Onderstepoort Journal of Veterinary Research, 70:175-186.

LOUW, J.P. 1989. Overberg research projects. VI. The biology and control of Oestrus ovis in sheep in the winter rainfall areas of the southern Cape. Onderstepoort Journal of Veterinary Research, 56:239-244.

MALAN, F.S., REINECKE, R.K. \& SCIALDO, ROSINA C. 1981. The recovery of helminths post-mortem from equines. II. Helminths and larvae of Gasterophilus from the gastro-intestinal tract and oestrids from the sinuses. Onderstepoort Journal of Veterinary Research, 48:145-147.

ROGERS, C.E. \& KNAPP, F.W. 1973. Bionomics of the sheep bot fly Oestrus ovis. Environmental Entomology, 2:11-23.

ZUMPT, F. 1965. Myiasis in man and animals in the Old World. London: Butterworths. 